\title{
Construction of Policy on Women Workers Who are Breastfeeding in Relation with The Fulfillment of The Children's Rights
}

\author{
Endah Pujiastuti ${ }^{1}$, Albertus Heru Nuswanto ${ }^{2}$ \\ \{endah.pujiastuti@usm.ac.id ${ }^{1}$,heru.nuswanto@usm.ac.id² \\ ${ }^{1,2}$ Faculty of Law, University of Semarang, Semarang, Indonesia
}

\begin{abstract}
The Government of the Republic of Indonesia has issued policies to provide legal protection for women workers who are breastfeeding. The policies issued in the context of fulfilling the rights of women workers and the rights of children based on the philosophy that the fulfillment of the necessities of life is a human right and constitutional right for every Indonesian citizen. Based on this conception, the results of this study examine government policies in providing legal protection for women workers to breastfeed their children. This is a normative legal research with the three approaches, namely statute, concepts, and analysis. The data used are secondary data collected through a literature study, then analyzed qualitatively. The results of this study indicate that the policies of women workers who are breastfeeding in relation to the fulfillment of children's rights have not provided strong and firm legal protection for women workers who are breastfeeding and also for breastfed children.
\end{abstract}

Keywords: breastfeeding, children, policy, women, workers.

\section{Introduction}

The government has issued several policies related to the protection of women workers, including the patronage of women workers who are still breastfeeding their children. The 1945 Constitution of the RI (UUD NRI 1945) stipulates that children have the right to the continuance of life, growth, and development. Children also have the right to get protection from hardness and discrimination.[1] Based on these provisions, it has implied that the fulfillment of the necessities of life is the human right and constitutional right for every Indonesian citizen. Refer to the provision of the constitution, women workers/workers whose children still need to breast milk (ASI) should get the appropriate opportunity to breastfeed their children. As we know, ASI is the mayor intake for a newborn child (baby), and this ASI in the first six months is very urgent to intake for the baby. Babies are entitled to exclusive breastfeeding for six months from birth.[2] This policy is certainly not only the responsibility of certain parties but also the responsibility of all related elements.

It is suspected that at this time the policies set by the Government have not yet run optimally. It is also suspected that there are several factors that influence the working of the policy, either from the aspect of substance, structure, or culture. When the three aspects do not work or there is an imbalance in one aspect, then the objective of the policy is not fully achieved. 
Based on the conditions, this article focuses on one aspect that influences the operation of the law, namely from the aspect of a substance by examining the construction of policy to fulfill the rights of women workers to breastfeed their children as a form of legal protection for women and also to realize the child's rights to obtain breast milk. We can examine political will in providing the fulfillment of rights for citizens, especially women workers and children. As for on research examining the formulation of problems focused on: How the construction of government policy on women workers to breastfeed her child in relationship with the fulfillment of child rights?

\section{Research Method}

Research on the construction of government policies on female workers to breastfeed their children in relation to the fulfillment of children's rights is a type of normative legal research. In essence, this type of research examines and analyzes the legal norms set by the authorized official for that.[4] The legal norm referred to here is the legislation relating to government policies towards breastfeeding female workers. There are three approaches used. The first approach used is the legislative approach. In addition to the statutory approach, a conceptual approach and analysis approach are also used.

This statutory appproach is used to study, explore, and examine the regulations that govern women workers. The application of the statutory approach by considering the structure of the norm in the form of a hierarchy of laws and the existence of the norm. The point here is whether the norm is in a general, old or new law.[5] Conceptual approach is used to analyze research problems that arise from the existence of empty norms in a legal system. This empty norm may or may not be the norm of a regulation that can be applied to a legal event.[5] The analytical approach is used to analyze legal material, find out the meaning contained in the terms used in the regulations conceptually, as well as find out their application in practice.[6] This approach is used to analyze policies on breastfeeding women workers that are currently applied.

The specification of this research is analytical descriptive research, where the results obtained on a particular population are systematically, factually, and accurately described.[7] This research will describe the results of the construction of policies on women workers who are breastfeeding in relation to the fulfillment of children's rights.

The research data used are secondary data. These secondary data include primary legal material and secondary legal material. Primary legal material includes eight laws and regulations. The first is UUD NRI 1945. Furthermore, there are four laws namely the Human Rights Act (Law Number 49 of 1999), the Children Protection Act (Law Number 23 of 2002), the Manpower Act (Law Number 13 of 2003), and the Health Act (Law Number 39 of 2009). Besides the Act, there is also Government Regulation concerning the Provision of ASI Exclusive (Regulation Number 33 of 2012, Joint Regulati on of the State Minister for Women's Empowerment, Minister of Manpower and Transmigration, and Minister of Health concerning Increased Provision of ASI During Working Time at Work Place(Number 48/MEN.PP/XII/2008, PER.27/MEN/XII/2008, and 1177/MENKES/PB/XII/2008), and Regulation of the Minister of Health of the Republic of Indonesia concerning Procedures for Providing Specific Facilities for Breastfeeding and/or Milking ASI (Regulation Number 15 of 2013).

The secondary legal material is taken from literature books related to the substance of this research. The collection of both legal materials was carried out through a literature study. The 
collection of both legal materials was carried out through a literature study. The secondary data is then analyzed using qualitative analysis methods. This qualitative analysis is intended to present research results in the form of sentence descriptions. Or in other words, the results of this study are the finding which is not descriptions through statistical procedures or other shapes of calculation.

\section{Research Results and Discussion}

The Republic of Indonesia Law on Manpower provides a different understanding between workers and workers/laborers. Labor has a wider scope than workers/laborers. Someone said as labor when he can do work that produces goods and/or services. The goods and/or services are used to meet their own needs and for the needs of the community. The definition of labor is not the same as the understanding of workers/laborers. What is meant by workers/laborers is every person who works (to another person/party) by receiving wages/rewards in other forms. It was implied here that both labor and workers/laborers in it include men and women. Therefore, in providing legal protection for male and female workers according to the law there is no distinction.

With regard to the nature of women who experience menstruation, childbirth, miscarriage, and breastfeeding, women workers are given special protections. If she feels pain on the first and second days of menstruation, she is not required to work. Women workers who give birth are entitled to a break of one and a half months before and after childbirth. What if he has a miscarriage she has the right to rest one and a half months after she gave birth to his child. Women workers who experience miscarriage (biological birth) are entitled to a break of one and a half months after miscarriage or following the statement of the obstetrician or midwife. The Manpower Act also stipulates that women workers who are still breastfeeding their children should be given the appropriate opportunity to breastfeed their children if this is done during work time. The purpose of the opportunity ought here to be related to the length of time given to women workers to breastfeed their children by paying attention to the availability of a place, following the conditions, and capabilities of the company, which is regulated in legislation or a collective labor agreement (CLA).

Based on the focus of this study, then in fact this is very closely related to the protection of children. They have inherent human rights that must be upheld. The regulation of children's rights is contained in the UUD NRI 1945 and the UN Convention on the Rights of the Child. Child protection efforts need to be implemented as early as possible or in other words since they were born. Starting from the conception of child protection that is whole, complete, and comprehensive, in conducting coaching, developing, and protecting children, community participation is needed. Related to this, parents (father and mother) as part of the community have a very urgent role in protecting children, and of the initial formation of the attitude and behavior of children starting from their parents.

Examining the policy construction on women workers who are breastfeeding in relation with the fulfillment of children's rights, of course we cannot remove our eyes to see the current legal conditions (ius constitutum) and the conditions to be achieved in the future (ius constituendum) which regulates women workers who are breastfeeding in relation with the fulfillment of children's rights. Or in other words, review das sein and das sollen. Tracing the government policies in the past up to now, these policies can be grouped in terms of time. The policy period for women workers who are breastfeeding in relation to the fulfillment of 
children's rights can be sorted out in the period after Indonesian Independence until 1965 (the Old Order era), from 1966 until 1998 (the New Order era), and from 1998 until now (the Reformation period).

During the old order period, policies on breastfeeding women workers in relation to the fulfillment of children's rights had not been explicitly stated in the specific legislation. Juridical footing that can be affirmed here is the basis of the state which is at the same time the state philosophy of Pancasila and UUD NRI 1945. The foundation of our country, Pancasila, has firmly provided basic foundation in protecting all citizens. The second precept and the fifth precept become the main foundation in the granting of this legal protection without ignoring the power of the other precepts, the first precept, the third precept, and the fourth precept. UUD NRI 1945 provides a basic arrangements for women workers. Women workers as part of Indonesian citizens receive constitutional protection as do the citizens in general.[1]

During the New Order era, legal protection for women workers who breastfeed their children was contained in the Human Rights Act, although it was not specific. This law provides that women get specific protection rights in the implementation of their job/profession. Protection is being direct at things that can endanger their safety and health about women's reproductive functions. Stressed also that female reproductive function, guaranteed, and protected by law.[8]

As for the reform period, the desire to fulfill the rights of breastfeeding women workers in relation with the fulfillment of children's rights is contained in the Child Protection Act[9], the Manpower Act[10], the Health Act, the Regulations of Government RI concerning The Provision of Exclusive ASI[11], the Joint Regulation of the Women's Empowerment Minister, the Manpower and Transmigration Minister, and the Health Minister regarding the Improvement in the Provision of ASI during Working Time at the Workplace[12], as well as the Regulation of the Health Minister concerning Procedures for Providing Specific Facilities for Breastfeeding and/or Expressing ASI.[13]

Of the three periods, the Government's political will in the reformation period seems to be stronger than in the previous two periods, although it cannot yet be said that there is a complete bias towards women workers who are breastfeeding. Broadly speaking, the policies related to women workers who are breastfeeding in relation with children protection can be seen in Tabel 1 below.

Table 1. Policies Against Women Workers Who Breastfeed Their Children in Relation with the Fulfillment of Children's Rights

\begin{tabular}{|c|c|c|c|c|}
\hline No & Law Regulation & Article & Paragrap & Note \\
\hline \multirow[t]{3}{*}{1} & \multirow[t]{3}{*}{ UUD NRI 1945} & $28 \mathrm{D}$ & (1) & \multirow{3}{*}{$\begin{array}{l}\text { This policy is a desire of } \\
\text { the Indonesian people to } \\
\text { build a democratic state } \\
\text { that carries out justice } \\
\text { and humanity. }\end{array}$} \\
\hline & & $28 \mathrm{G}$ & (1) & \\
\hline & & $28 \mathrm{H}$ & (1) & \\
\hline
\end{tabular}




\begin{tabular}{|c|c|c|c|c|}
\hline \multirow[t]{2}{*}{2} & \multirow[t]{2}{*}{ The Human Rights Act } & 49 & (2) & \multirow[t]{2}{*}{$\begin{array}{l}\text { Provision of special } \\
\text { protection for women's } \\
\text { reproductive functions } \\
\text { including health services } \\
\text { related to menstruation, } \\
\text { pregnancy, childbirth } \\
\text { and providing } \\
\text { opportunities for } \\
\text { breastfeeding children. }\end{array}$} \\
\hline & & 49 & (3) & \\
\hline \multirow[t]{2}{*}{3} & \multirow[t]{2}{*}{ The Manpower Act } & 6 & & $\begin{array}{l}\text { Non-discriminative } \\
\text { treatment without } \\
\text { ignoring gender aspects }\end{array}$ \\
\hline & & 83 & & $\begin{array}{l}\text { Time opportunities for } \\
\text { breastfeeding their } \\
\text { babies and availability of } \\
\text { places to breastfeed } \\
\text { directly or indirectly (by } \\
\text { milking) }\end{array}$ \\
\hline \multirow[t]{3}{*}{4} & \multirow[t]{3}{*}{ The Health Act } & 128 & (2) & \multirow[t]{3}{*}{$\begin{array}{l}\text { Regulating is an appeal } \\
\text { for support to } \\
\text { breastfeeding mothers }\end{array}$} \\
\hline & & 129 & (1) & \\
\hline & & 142 & $(1)$ & \\
\hline 5 & $\begin{array}{l}\text { Government Regulation } \\
\text { concerning Provision of } \\
\text { Exclusive ASI }\end{array}$ & 30 & (1) & $\begin{array}{l}\text { Regulating is an appeal } \\
\text { for support for the } \\
\text { implementation of the } \\
\text { Exclusive ASI Program }\end{array}$ \\
\hline \multirow[t]{2}{*}{6} & \multirow[t]{2}{*}{$\begin{array}{l}\text { Regulation of the Health } \\
\text { Minister concerning } \\
\text { Procedures of the Provision } \\
\text { of Specific Facilities for } \\
\text { Breastfeeding and/or } \\
\text { Blushing ASI }\end{array}$} & 6 & (1) & \multirow[t]{2}{*}{$\begin{array}{l}\text { Regulating is an appeal } \\
\text { for support for the } \\
\text { provision of space for } \\
\text { exclusive breastfeeding }\end{array}$} \\
\hline & & 6 & (2) & \\
\hline
\end{tabular}




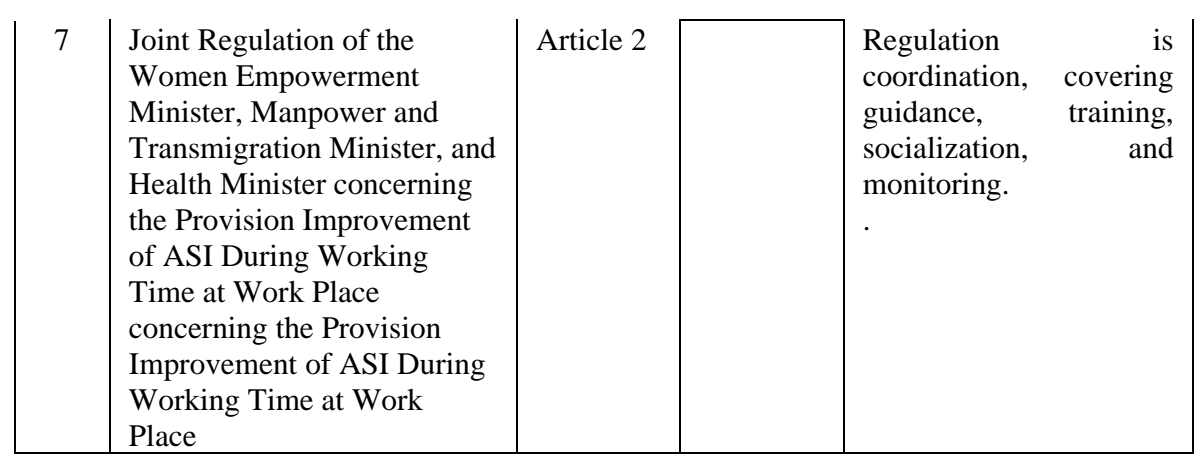

Source: Secondary data after being processed, 2020

In relation with the efforts to provide protection for breastfeeding mothers, the International Labor Organization (ILO) has issued Convention No. 180 of 2000 concerning Maternity. Article 10 of ILO Convention No. 183 of 2000 regulates breastfeeding mothers with 2 (two) paragraphs of regulation. The clause in 2 (two) paragraphs stipulates that every woman worker is given the right to time to breastfeed her child. The time is taken by women workers to breastfeed their children must be calculated as work time and should be paid. The Government of the Republic of Indonesia has adopted this regulation but has not yet ratified the convention. The regulation is stated in the Manpower Act Article 83.

One aspect that cannot be ignored in policies on breastfeeding women workers in relation with the fulfillment of children's rights is the aspect of law enforcement. This aspect of law enforcement certainly cannot be released from the regulation of sanctions for not fulfilling the substance of the policies that have been determined.

Table 2. Provisions for Sanctions on Policies Against Breastfeeding Women in Relation with the Fulfillment of Children's Rights

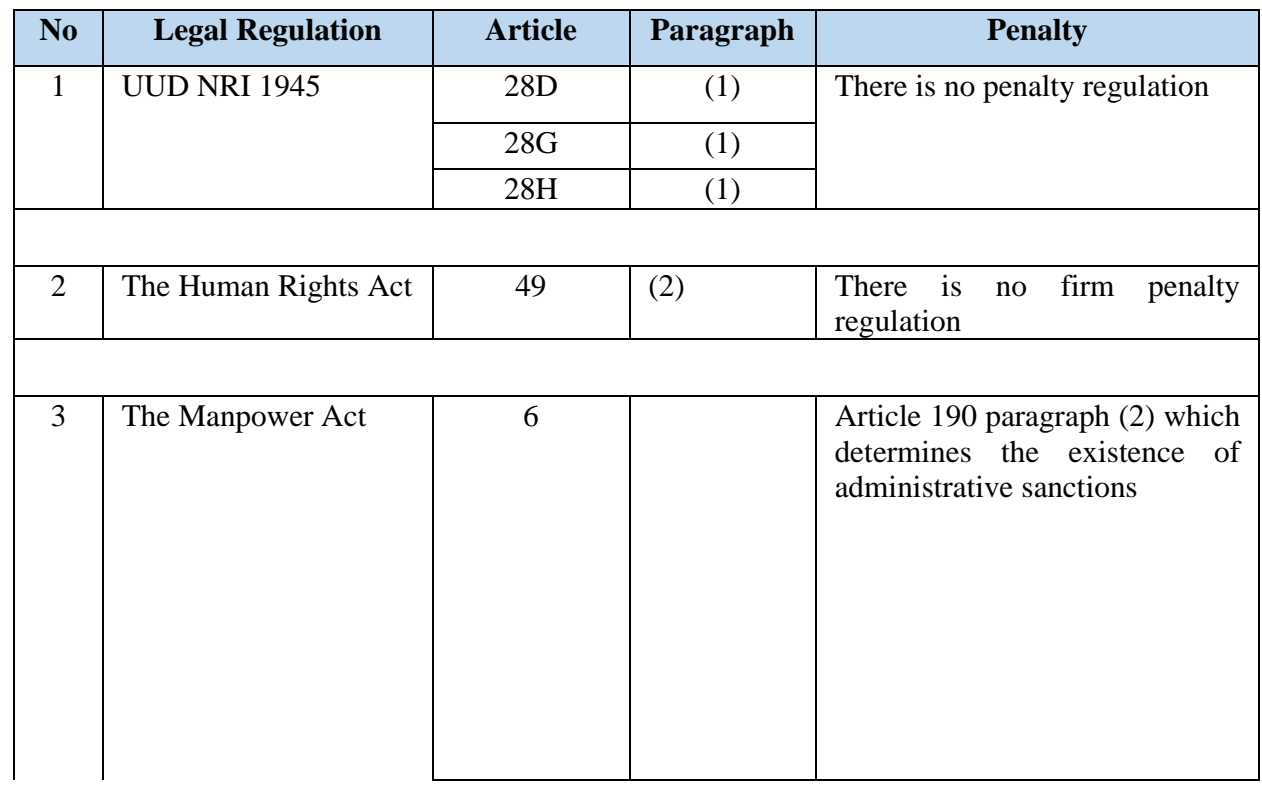




\begin{tabular}{|c|c|c|c|c|}
\hline & & 83 & & There is no penalty regulation \\
\hline \multirow[t]{3}{*}{4} & The Health Act & 128 & (1) & $\begin{array}{l}\text { There is no penalty regulation, } \\
\text { but Article } 200 \text { stipulates that } \\
\text { violation of Article } 128 \\
\text { paragraph (2) is a form of } \\
\text { imprisonment and fines. }\end{array}$ \\
\hline & & 129 & (1) & \multirow[t]{2}{*}{ There is no penalty regulation } \\
\hline & & 142 & (1) & \\
\hline 5 & $\begin{array}{l}\text { Government } \\
\text { Regulation concerning } \\
\text { Provision of Exclusive } \\
\text { ASI }\end{array}$ & 30 & (1) & Does not regulate penalty \\
\hline \multirow[t]{2}{*}{6} & \multirow[t]{2}{*}{$\begin{array}{l}\text { Regulation of the } \\
\text { Health Minister } \\
\text { concerning Procedures } \\
\text { of the Provision of } \\
\text { Specific Facilities for } \\
\text { Breastfeeding and/or } \\
\text { Blushing ASI }\end{array}$} & 6 & (1) & \multirow[t]{2}{*}{ Does not regulate penalty } \\
\hline & & 6 & (2) & \\
\hline 7 & $\begin{array}{l}\text { Joint Regulation of the } \\
\text { Women Empowerment } \\
\text { Minister, Manpower } \\
\text { and Transmigration } \\
\text { Minister, and Health } \\
\text { Minister concerning } \\
\text { the Provision } \\
\text { Improvement of ASI } \\
\text { During Working Time } \\
\text { at Work Place }\end{array}$ & 2 & & Does not regulate penalty \\
\hline
\end{tabular}

Source: Secondary data after being processed, 2020

From Table 2, we can observe the absence of strict and strong penalties on policies against breastfeeding women in relation to the fulfillment of children's rights set by the Government. Strict penalties are only stipulated in the Manpower Act Article 190 paragraph (2) which provides administrative penalties for violations of the provisions of Article 6 of the Manpower Act. Then the provisions of Article 200 of the Health Act stipulate that violation of Article 128 paragraph (2) is a form of imprisonment and fines. In addition to the two articles, there is no penalty related to the regulation of women workers who are breastfeeding.

Based on the policies that have been set by the government, the construction of policies for women workers who are breastfeeding in relation with the fulfillment of children's rights has not provided strong and strict legal protection for women workers who are breastfeeding and also breastfed children. The government still has not given much attention to women who 
are breastfeeding, in the long run, this is tight related to the quality of children. From the philosophical aspect, the fulfillment of the principles of humanity and the principle of justice for breastfeeding women and breastfed children has not been well realized. From the juridical aspect, there are still weaknesses in the regulation of penalties, including horizontal and vertical harmonization among regulations. If we look at the sociological aspect, the concern of the elements in society towards women who are breastfeeding cannot be said to be in the high care category.

\section{Conclusion}

As explained in the discussion section and the results of the research, it can be concluded that policies on breastfeeding women workers in relation to the fulfillment of children's rights in Indonesia are outlined in several regulations. Since the independence of the Republic of Indonesia until now, the policy products that were rolled out during the reform period were more than in the previous periods. The political will of the government for women who are breastfeeding is also stronger even though it has not yet fully provided legal protection for women who are breastfeeding their children (especially women workers) and also breastfed children. The construction of policies for women workers who are breastfeeding in relation to the fulfillment of children's rights has not provided strong and strict legal protection for women workers who are breastfeeding and also breastfed children. Regulations in policies are for the most part appeals which are not followed by imposing penalties on those who do not implement the substance of the policies.

Based on these conditions, to realize an ius constituendum that provides benefits for all parties, concrete actions from all elements of the nation are needed so that breastfeeding women workers get the proper protection and at the same time provide protection against the fulfillment of children's rights to get breast milk which will be very beneficial in its growth. Therefore, the government should re-conceptualize policies related to the fulfillment of the rights of breastfeeding women workers that lead to and strengthen the realization of constructive, humanitarian, and implementative policies. Community support is also needed in the respective capacities of women, entrepreneurs, workers, non-governmental organizations, academics, and others.

\section{Acknowledgments}

Our thanks for the head of the University of Semarang (USM), the LPPM USM, and the Faculty of Law USM. Facilities and support are always given to us in carrying out our research.

\section{References}

[1] Sekretariat Negara Republik Indonesia, Undang-Undang Dasar Negara Republik Indonesia Tahun 1945. Jakarta.

[2] _ Undang-Undang Republik Indonesia Nomor 36 Tahun 2009 tentang Kesehatan. Jakarta, 2009.

[3] P. Mahmud Marzuki, Penelitian Hukum, VII. Jakarta: Prenada Media, 2011.

[4] Salim HS and E. S. Nurbani, Penerapan Teori Hukum pada Penelitian dan Disertasi. Jakarta: 
RadjaGrafindo Persada, 2013.

[5] I. M. P. Diantha, Metode Penelitian Hukum Normatif dalam Justifikasi Teori Hukum. Jakarta: Prenada Media, 2016.

[6] J. Ibrahim, Teori dan Metode Penelitian Hukum Normatif. Malang: Bayu Media, 2006.

[7] B. Sunggono, Metode Penelitian Hukum. Jakarta: RadjaGrafindo Persada, 2003.

[8] Sekretariat Negara Republik Indonesia, Undang-Undang Republik Indonesia Nomor 49 Tahun 1999 tentang Hak Asasi Manusia. Jakarta, 1999.

[9] _ Undang-Undang Republik Indonesia Nomor 23 Tahun 2002 tentang Perlindungan Anak. Jakarta, 2002.

[10] _ Undang-Undang Republik Indonesia Nomor 13 Tahun 2003 tentang Ketenagakerjaan. Jakarta, 2003.

[11] __ Peraturan Pemerintah Republik Indonesia Nomor 33 Tahun 2012 tentang Pemberian Air Susu Ibu Eksklusif. Jakarta, 2012.

[12] __ Peraturan Bersama Menteri Negara Pemberdayaan Perempuan, Menteri Tenaga Kerja dan Transmigrasi dan Menteri Kesehatan Nomor 48/MEN.PP/XII/2008, PER.27/MEN/XII/2008 dan 1177/MENKES/PB/XII/2008 Tahun 2008 tentang Peningkatan Pemberian Air Susu Ibu Selama Waktu Kerja di Tempat Kerja. Jakarta, 2008.

[13] __ Peraturan Menteri Kesehatan Republik Indonesia Nomor 15 Tahun 2013 tentang Tata Cara Penyediaan Fasilitas Khusus Menyusui dan/atau Memerah Air Susu Ibu. Jakarta, 2013. 